\title{
A statute of unintended consequences? The impact of the Charities and Trustee Investment (Scotland) Act 2005 on non-Scottish charities operating in Scotland
}

PATRICK FORD

\author{
Lecturer in Law and Member of the Charity Law Research Unit, \\ University of Dundee*
}

\begin{abstract}
Introduction
$\mathrm{T}$ The central question addressed by this article is whether the provisions of the Charities and Trustee Investment (Scotland) Act $2005^{1}$ as to "foreign" or "non-Scottish" charities - that is, charities established outside Scotland - are satisfactory. The article concludes that they are not. Explaining that conclusion will involve saying something about the background to the Act and the policies behind it, outlining the key features of the supervisory regime set up by the Act, including the Scottish "charity test", and examining the "foreign charities" provisions in the light of the Act's policy objectives. That in turn will involve considering those provisions from the standpoint of non-Scottish charities themselves, particularly charities established in England and Wales, and suggesting that the requirement of dual regulation may have the unintended effect of discouraging such charities from engaging in beneficial activity in Scotland. As a postscript the article considers how a different approach based on mutual recognition might have made beneficial operation in Scotland more attractive to charities established outside the jurisdiction, and recommends adoption of such an approach in amending legislation. It is suggested that a similar approach might recommend itself to those legislating for charities' supervision in Northern Ireland and the Republic of Ireland. ${ }^{2}$
\end{abstract}

\section{Background}

The 2005 Act is an Act of the Scottish Parliament. The Parliament may legislate for the "creation, operation, regulation and dissolution of charities" in Scotland and for the fiscal treatment of charities at the level of local taxation, but it has no power to legislate for tax relief for charities at United Kingdom level, since that is a matter reserved to the Westminster Parliament. ${ }^{3}$ This is an important limitation, because the previous regulatory arrangements

* The article has been developed from a paper given at the National Council for Voluntary Organisations and Voluntary Sector Studies Network "Researching the Voluntary Sector" Conference in September 2007 as one in a panel on The Impact of Regulatory Reform. The author would like to thank his fellow panellists, Dr Oonagh Breen, Ms Siobhan McGee and Professor Gareth Morgan for their helpful comments on the paper.

1 Hereinafter "the Act" or the "2005 Act" as the context requires. The Act's main regulatory provisions came into force on 1 April 2006.

2 See Charities Bill (NIA Bill 9/07); Charities Bill (No. 31 of 2007).

3 Scotland Act 1998, s. 30, Sch. 5, Pt II, Heads C1 and A1. 
for "charities" in Scotland, set up under Part I of the Law Reform (Miscellaneous Provisions) (Scotland) Act 1990, ${ }^{4}$ and now replaced by the 2005 Act system, were inextricably bound up with tax relief for charities under United Kingdom legislation. Scotland has its own common law equivalent of the English charitable trust, the public trust, ${ }^{5}$ but rather than build on the common law to produce a truly indigenous system of supervision for non-profit bodies constituted for public benefit, ${ }^{6}$ the 1990 Act instead took the technical English definition of charity as the basis of its entirely statutory system of supervision of "Scottish charities". The English definition of charity had originally been introduced into the law of Scotland through the medium of United Kingdom taxing statutes: under such statutes tax relief for bodies with "charitable purposes" is granted, in Scotland as in England and Wales, by reference to the technical meaning of "charitable" in English law. ${ }^{7}$ The 1990 Act adopted the simple device of defining a "Scottish charity" for regulatory purposes as a body recognised by the Commissioners of Inland Revenue as charitable for tax relief purposes ${ }^{8}-$ as charitable, in other words, in the sense of the term in English law.

The arrangement had its advantages: it meant that there was a common definition of charity across the United Kingdom for both tax and regulatory purposes, ${ }^{9}$ and that bodies in Scotland which enjoyed the benefits of United Kingdom charitable tax relief were subject to official supervision as "charities" in the same way as their counterparts elsewhere in the United Kingdom. ${ }^{10}$ The Scottish Parliament might have retained the device in the 2005 Act but chose not to, ${ }^{11}$ opting instead for its own "charity test" as a way of identifying bodies eligible for registration as "charities" in Scotland. The charity test remains, however, a derivative of the English definition. The intention of the Scottish legislature was that the test should be "very similar [to] and compatible with" the revised definition of charity then being proposed for England and Wales (and for United Kingdom tax purposes) in the English Bill which was to become the Charities Act 2006. ${ }^{12}$ In the result, the charity test is, indeed, very like the English definition of charity provided for by the 2006 Act, yet significantly different.

The same is true of the new Scottish charities system as a whole: it is an attempt to replace the rudimentary 1990 Act system, which almost from its inception had been criticised as inadequate, ${ }^{13}$ with something closer to the much longer-established and more sophisticated system of charities' supervision in England and Wales, but with variations peculiar to Scotland. The hybrid Anglo-Scottish character of the 2005 Act is attributable in

4 Hereinafter the "1990 Act".

5 See Lord Ross et al., "Trusts, trustees and judicial factors" in The Laws of Scotland: Stair Memorial Encyclopaedia, vol. 24 (Edinburgh: Law Society of Scotland/Butterworths, 1989), paras 85-9.

6 See P Ford, "Supervising charities: a Scottish-civilian alternative" (2006) 10 Edin LR 352-85.

7 Special Commissioners for the Purposes of Income Tax v Pemsel [1891] AC 531, as explained in IRC v City of Glasgow Police Atbletic Association [1953] AC 380, per Lord Reid at 403. For current relieving provisions from direct UK taxation, see, e.g. Income and Corporation Taxes Act, s. 505; see also n. 59 below.

81990 Act, s. 1(7). There was also a requirement of territorial connection with Scotland. The Inland Revenue is now incorporated in HM Revenue and Customs (hereinafter HMRC).

9 See, latterly, Charities Act 1993, s. 97(1), and Charities Act (Northern Ireland) 1964, s. 35.

10 As recommended in the Woodfield Report: Sir Philip Woodfield, Efficiency Scrutiny of the Supervision of Charities (London: Home Office and HM Treasury, 1987, para. 144.

11 Policy Memorandum issued with the Charities and Trustee Investment (Scotland) Bill (SP Bill 32) (hereinafter "Policy Memorandum"), para. 53.

12 Hereinafter the "2006 Act". See Policy Memorandum, para. 53. The English Bill and the Scottish Bill initially ran in parallel through their respective parliamentary processes, but the English Bill was derailed by the 2005 general election with the result that the Scottish Bill reached the statute book first.

13 See Scottish Council for Voluntary Organisations, Faith and Hope in Charity? (Edinburgh: SCVO, 1994). 
part to its attempt to marry the recommendations of a report of the Strategy Unit of the Cabinet Office for the regulation of charities in England and Wales ${ }^{14}$ with those of an earlier report specific to Scotland, the report of the Scottish Charity Law Review Commission, chaired by Ms Jean McFadden. ${ }^{15}$ Arguably, the Act falls between the two stools of faithful imitation of a system tried and tested south of the border and construction from first principles of a genuinely Scottish alternative. ${ }^{16}$ What matters in practice, however, is whether the legislation as enacted, Anglo-Scottish hybrid though it may be, gives satisfactory effect to its declared policy objectives.

\section{Policy of the Act}

The overall policy objective of the Act is clear. It is "to establish a satisfactory regulatory regime that will encourage public confidence in charities whilst not over-burdening the charity sector with bureaucracy". ${ }^{17}$ During the long lead-up to legislative action on the McFadden Report public confidence in the 1990 Act system had been shaken by two prominently reported charity abuse scandals ${ }^{18}$ and it is unsurprising, therefore, that the emphasis of the Policy Memorandum issued with the reforming Bill should have been on "robust regulation" to ensure good governance and accountability. ${ }^{19}$ There is an important facilitative dimension to the Act, certainly, arising from acceptance at policy level of "a need to assist charities to operate effectively in a modern society", 20 and, accordingly, there is provision for improved reorganisation procedures for charities and access to a new dedicated legal form. ${ }^{21}$ The principal thrust of the Act, however, "is against the corrupt use and abuse of the word 'charity', and against the abuse of people who give their time and resources to support good works". ${ }^{22}$ Its aim is that members of the public in Scotland should be able to contribute to "charities" in the knowledge that the recipient bodies will be subject to a rigorous system of supervision.

The benefactors of charities - those who contribute to charities as donors or volunteers - are not, of course, the only people who have an interest in the robust regulation of charities. ${ }^{23}$ Most obviously, the beneficiaries of charities - the members of the public at the receiving rather than the contributing end of charities - have an interest in the state's ensuring that the charities which set out to help them do so in an accountable and wellorganised way. Clearly, however, the interests of benefactors and beneficiaries overlap: benefactors contribute because they want to help beneficiaries, and if beneficiaries are helped honestly and effectively that is good both for the beneficiaries themselves and for the benefactors who see their contributions applied as they would have hoped. But a policy

14 Private Action, Public Benefit: A review of charities and the wider not-for-profit sector (London: Strategy Unit, Cabinet Office, 2002) (hereinafter "Strategy Unit Report”).

15 Charity Scotland (Edinburgh: Scottish Executive, 2001) (hereinafter the "McFadden Report"). For the joint influence of the Strategy Unit and McFadden Reports, see S Cross and P Ford, Greens Annotated Acts: The Charities and Trustee Investment (Scotland) Act 2005 (Edinburgh: W Green, 2006) (hereinafter "Cross and Ford"), pp. 6-7.

16 See P Ford, “The Charities and Trustee Investment (Scotland) Bill: falling between two stools?” (2005) 16 KCLJ 1-28, 5-7.

17 Policy Memorandum, para. 24.

18 See statements of the Minister for Communities, Official Report, Plenary Session, 28 May 2003, cols 133-6 and Plenary Session, 24 September 2003, cols 1955-8.

19 Policy Memorandum, para. 3.

20 Ibid., para. 4.

21 Ibid., paras 5, 37, and 42.

22 Remark of the Deputy Minister for Communities, Official Report, 9 June 2005, col. 17821.

23 For a fuller analysis see P Ford, "The Charities and Trustee Investment (Scotland) Act 2005: a stakeholder assessment” (2007) Juridical Review 179-219. 
focus on the interests of benefactors is natural enough in any government eager to maximise the potential contribution of the voluntary sector, and charities in particular, to the delivery of public services. ${ }^{24}$ The value to the state in encouraging public confidence in charities lies in securing the private contributions of the public as benefactors to the provision to the public as beneficiaries of services which must otherwise be funded by government. ${ }^{25}$ The particular emphasis in the Policy Memorandum on charities, as opposed to other voluntary organisations engaged in similarly publicly beneficial activities, can be attributed to an assumption that "charities" attract a more favourable response from the donating and volunteering public than bodies soliciting support without the benefit of the label. ${ }^{26}$ In any event, the primary intention of the Act is "to protect the charity "brand". 27

Protection of the charity brand is a concern, too, of the English system, ${ }^{28}$ but in England and Wales the importance of the "prestige" attaching to charitable status is arguably matched, if not exceeded, by the value of the concomitant tax reliefs. ${ }^{29}$ As mentioned, however, the Scottish legislators have chosen to dissociate Scottish charitable status from charitable tax relief at United Kingdom level, so that - even though charitable taxation relief at local level is now linked directly to registration with the Scottish charity regulator $^{30}$ - the real raison d'etre of the Act is to give the new regulator jurisdiction over bodies which make use of the charity brand in Scotland.

\section{Scottish system of charities supervision outlined}

It may be helpful at this point to sketch out the main features of the new Scottish system. As explained, its model is the system for the supervision of charities in England and Wales, adapted for Scotland in the light, in particular, of certain key recommendations of the McFadden Report. ${ }^{31}$ Overall, the picture is one of convergence with the English system in the broad but divergence in detail.

Thus, there is a new Scottish charity regulator, OSCR, 32 modelled on the Charity Commission, yet with lesser powers. ${ }^{33}$ The powers of the Scottish regulator are underpinned by statutory powers of intervention by the Court of Session broadly in the same way, but only broadly, as those of the Charity Commission are underpinned by the inherent powers of the High Court. ${ }^{34}$ There is a new register of charities in Scotland, but

24 Policy Memorandum, para. 4. The new Scottish Government which took power after the 2007 elections to the Scottish Parliament has similar hopes: see statement of the Cabinet Secretary for Finance and Sustainable Growth on Local Government Finance Settlement 2008-11, Official Report, Plenary Session, 13 December 2007, col. 4465.

25 An estimate from 2004 put donations to Scottish charities from the general public at approximately $f^{240} \mathrm{~m}$ a year, or around $12 \%$ of the sector's income: Draft Charities and Trustee Investment (Scotland) Bill: Consultation paper (Edinburgh: Scottish Executive, 2004), p. 36.

26 The assumption has been tested to some extent by research in England and Wales but without conclusive results: see Opinion Research Leader, Report of Findings of a Survey of Public Trust and Confidence in Charities (London: Charity Commission, 2005).

27 Policy Memorandum, para. 3.

28 See Charities Act 1992, s. 63, discussed below.

29 See C Mitchell, "Redefining charity in English law" (1999) 13 Trust Law International 21-47, 28.

30 Local Government (Financial Provisions etc) (Scotland) Act 1962, s. 4. as amended by 2005 Act, s. 75, Sch. 4, para. 2: local authorities must grant charities registered with OSCR relief from non-domestic rates at a minimum of $80 \%$.

31 See n. 15 above.

32 Office of the Scottish Charity Regulator: 2005 Act, s. 1.

332005 Act, ss. 31 and 32; cf. Charities Act 1993 (hereinafter the "1993 Act"), ss. 18 and 19. References to the 1993 Act are to the Act as amended by the 2006 Act.

342005 Act, ss. 34-7; cf. 1993 Act, s. 16; see also Re J W Laing Trust [1984] Ch 143. 
with different criteria for registration - over and above those incorporated in the charity test - from those applicable in England and Wales. ${ }^{35}$ Much of the Act is devoted to provisions concerned with the monitoring and accountability of charities, each plainly inspired by originals in the English legislation but with significant differences of drafting: there are controls on charity names, ${ }^{36}$ and on references to charitable status; ${ }^{37}$ there is a requirement for approval by OSCR of major alterations to a charity's constitution; 38 there are obligations on charities to provide information direct to members of the public, independently of what is available on the register; ${ }^{39}$ and there is a new Scottish accounting and reporting regime, broadly similar to the English one but by no means identical. 40

Again, the 2005 Act sets out to reproduce by statute for the "charity trustees" 41 of charities registered with OSCR the regime of equitable duties incumbent on charity trustees in England and Wales, ${ }^{42}$ yet in two specific respects the Scottish duties are notably different from those of the English model. The 2005 Act authorises, subject to certain restrictions, the remuneration of charity trustees for their services as such, and not only for the provision of unrelated services, ${ }^{43}$ whereas in England and Wales the 2006 Act authorises remuneration only for services which might have been provided by a non-charity trustee. ${ }^{44}$ And - in the view of OSCR - the 2005 Act treats the payment by a charity of the premiums for trustee indemnity insurance as a form of remuneration of the charity trustees the insurance protects, and as ruled out, in effect, for charities registered in Scotland by the restrictions applicable to other forms of remuneration. ${ }^{45}$ In England and Wales, on the other hand, the 2006 Act grants a default authority to charities to provide indemnity insurance for their charity trustees. ${ }^{46}$

The facilitative objective of the Act is implemented, as mentioned, by improved reorganisation provisions and access (in prospect, at least) to a new limited liability form. ${ }^{47}$ The reorganisation sections are modelled in part, but only in part, on the cy-près provisions of the English legislation, ${ }^{48}$ and the new form, the Scottish Charitable Incorporated Organisation (SCIO), is a close relation, though not a clone, of the nascent English Charitable Incorporated Organisation. ${ }^{49}$ The Act also introduces new Scottish controls on fundraising undertaken by or on behalf of "benevolent bodies", controls which replicate those applicable in England and Wales to "charitable institutions", yet not exactly. ${ }^{50}$ The Scottish controls are,

35 See pp. 206-7 below under "Registration".

362005 Act, ss. 10, 11, 12; cf. 1993 Act, ss. 6 and 7.

372005 Act, ss. 13-15; cf. 1993 Act, ss. 5, 67 and 68.

382005 Act, ss. 16 and 17; cf. 1993 Act, ss. 64 and 66.

392005 Act, s. 23; cf. 1993 Act, s. 47.

402005 Act, ss. 44-6; cf. 1993 Act, ss. 41-49A and 66A. For a helpful summary of the differences see G G Morgan, "Cross-border complexities” (2007) Charity Finance (April) 39.

41 The term is defined by s. 106 of the 2005 Act in exactly the same way as in s. 97(1) of the 1993 Act.

42 This is the intended effect of ss. 66 and 67 of the 2005 Act: see commentary on those sections in Cross and Ford.

432005 Act, ss. 67 and 68: the provisions permit a person employed by a charity to act as a charity trustee.

441993 Act, ss. 73A and 73B.

452005 Act, s. 67: for OSCR's view, see: www.oscr.org.uk/trusteeindemnityinsurance.stm. The Scottish Government accepts that any restriction on indemnity insurance was "unintended" and is considering "appropriate action": see written answer by the Minister for Community Safety, Official Report, 22 January 2008.

461993 Act, s. 73F.

47 The provisions for the new form are not yet in force.

482005 Act, ss. 39-43; cf. 1993 Act, ss. 13-14B.

492005 Act, ss. 49-64; cf. 2006 Act, s. 34 and Sch. 7.

502005 Act, ss. 79-83 and 84-92; cf. Charities Act 1992, Pt. II and 2006 Act, ss. 67-9 and 45-66. 
however, the same as their southern equivalents in that they permit, subject to regulation, fundraising from the public, not only by bodies recognised technically as charities and fully regulated as such, but also by bodies with "benevolent" or "philanthropic" purposes which are not otherwise subject to regulation under the charities regime. ${ }^{51}$

It is worth looking at certain of the divergences from the English model more closely, partly because they are likely to be of special concern to English and Welsh charities contemplating registration in Scotland, 52 and partly because they have produced, or threaten to produce, unintended effects which those legislating for charities in Northern Ireland and the Republic of Ireland may wish to beware of.

\section{REGISTRATION}

The policy objective of protecting the charity brand is given effect by the "key principle" of the Act that any body wishing to represent itself as a "charity" in Scotland must register with OSCR. ${ }^{53}$ Indeed, a body only becomes a charity in Scotland - and entitled to describe itself as such - by registering. ${ }^{54}$ In other words, a body which would qualify for registration under the charity test is not entitled to call itself a charity until it has been entered in the register. This is different from the position in England and Wales where an institution is a charity simply by virtue of having "charitable purposes" (in the English sense) and is obliged to register with the Charity Commission as a result of that status unless exempt or excepted from registration. ${ }^{55}$ Registration creates charitable status in Scotland but in England and Wales follows it.

In Scotland, there are no exemptions or exceptions from registration, ${ }^{56}$ apart from the very limited one in favour of non-Scottish charities contained in s. 14 of the 2005 Act and to be discussed fully below. Any body, regardless of size, or of territorial origin, which is not covered by this exception but which does call itself a charity in Scotland without registering, is liable to preventative action by OSCR and the Court of Session. ${ }^{57}$ The corollary, however, is that no body, even one clearly eligible for registration under the charity test, is obliged to register unless it wishes to represent itself as a charity. The system assumes, in other words, that bodies will opt into the regime of supervision voluntarily in return for its concomitant advantages. Principal among these, of course, is freedom to use the charity brand, but the others, as we have seen, are automatic relief from local taxation, and availability of the new reorganisation facilities and the SCIO. ${ }^{58}$ On the other hand, as we have also seen, registration does not bring with it charitable tax relief at United Kingdom level, which depends on a separate application to HMRC for recognition that the purposes

51 Pt 3 of the 2005 Act enlarges the default investment powers of Scottish trustees, bringing them into line with those of English trustees under the Trusts Act 2000. Pt 3 does not apply to charities as such, but charities constituted as public trusts stand to benefit incidentally.

52 See pp 219-20 below "To register or not to register?".

53 OSCR, Guidance on Registration for England and Wales Charities (Dundee: OSCR, 2006) (hereinafter "Guidance on Registration"), s. 2.

542005 Act, s. 106.

551993 Act, s. 3A.

56 Cf. 1993 Act, s. 3A. Excepted charities in England and Wales include "small charities", i.e. those with a gross annual income of less than $f, 5000$.

572005 Act, ss. 13, 28, 31 and 34 .

58 The 2005 Act, s. 96, grants charities registered with OSCR a default power to invest in common investment funds (CIFs) established by the Charity Commission; cf. 1993 Act, ss. 24 and 25: but the 2006 Act, s. 23 limits the participation of such charities to those eligible for United Kingdom tax relief, and allows participation by bodies which are eligible for tax relief but not registered with OSCR. Accordingly, participation in CIFs is in reality an advantage of charitable status for United Kingdom-level tax purposes, not of registration with OSCR. 
of the body in question are "charitable" in the English sense, ${ }^{59}$ and is equally available to bodies not registered with OSCR. It should be remembered, too, that the value of automatic fiscal relief at local level is relative only: local authorities have power to grant discretionary relief to a wide range of publicly beneficial organisations other than charities. ${ }^{60}$ Nor, since the fundraising system is open as much to merely benevolent or philanthropic bodies as to charities, does registration bring exclusive eligibility to raise funds from the public in Scotland. Again, a public trust may be constituted and may operate freely under the common law without any reference to OSCR or the charity test. ${ }^{61}$

One unintended consequence of the registration arrangements under the 2005 Act may turn out to be, therefore, that public benefit organisations in Scotland will look very carefully at the advantages and disadvantages of opting into the charities' supervisory regime before committing themselves to registration. Bodies which, under the 1990 Act, would have applied for Scottish charity status as part and parcel of obtaining United Kingdom-level tax relief may now hesitate to register with OSCR if they judge that the burdens of the regime outweigh its comparatively modest advantages. ${ }^{62}$ It is no longer a foregone conclusion, in other words, that registration as a charity is the obvious way forward for a body seeking to confer public benefit in Scotland.

\section{DE-REGISTRATION AND ASSET LOCK}

There is a real possibility, therefore, that a proportion of the voluntary organisations active in Scotland which under the old arrangements would have opted unhesitatingly for charitable status may choose to operate outside the ambit of the new charities regime. There is little sign so far of a change of practice along these lines, ${ }^{63}$ but the transitional arrangements for bodies previously recognised as Scottish charities (under the 1990 Act) are such that any change is likely to impact on the overall composition of the voluntary and charities sectors only in the long term. All bodies in Scotland recognised as charitable by HMRC on 1 April 2006 were automatically entered in the new register, and there is a strong disincentive to their choosing to deregister (as they may) ${ }^{64}$ in the "asset lock" which applies on deregistration. ${ }^{65}$ The effect of the lock is that the assets held by a body at the moment of deregistration are held in a constructive trust for its charitable purposes as they stood immediately before deregistration and that in respect of those assets the deregistered body continues to be subject to a modified version of the principal compliance regime. ${ }^{66} \mathrm{In}$ short, a body removed from the register remains subject to compliance in respect of its preremoval assets but retains none of the advantages of registration.

59 See n. 7 above. The relevant sense is now adjusted by the 2006 Act, ss. 1-3, 5(1) and (2), provisions applicable in Scotland for United Kingdom tax purposes by virtue of s. 80 of that Act. The adjustment took effect on 1 April 2008. OSCR and HMRC have, however, entered into administrative arrangements to expedite applications for UK tax relief by bodies registered with OSCR: see Joint Statement dated 19 February 2008 at www.hmrc.gov.uk/charities/oscr-hmrc-statement082202.pdf (accessed 16 July 2008).

60 Local Government (Financial Provisions, etc.) (Scotland) Act 1962, s. 4(5). See n. 30 above.

61 A public trust in Scotland is simply a trust in which "the beneficial interest is intended for the benefit of a section of the public": Ross et al., "Trusts, trustees and judicial factors" (n. 5 above), para. 6.

62 See Ford, "A stakeholder assessment" (n. 23 above), pp. 207-16.

63 OSCR dealt with over 1600 applications in the first 18 months of the new regime: OSCR, Meeting the Charity Test: Draft guidance for consultation (Dundee: OSCR, 2008) (hereinafter "Draft Guidance"), p. iii; but for the beginnings of a change in attitude among professional advisers see Tax Committee of the Law Society of Scotland, "Professional Briefing: Charities" (2008) 53(1) JLSS 43.

642005 Act, s. 18.

652005 Act, s. 19.

662005 Act, s. 19(1)-(3). 
The asset lock will affect not only bodies which choose to de-register but also bodies removed from the register by OSCR because they no longer meet the charity test. ${ }^{67}$ Those most likely to be affected are bodies established in Scotland which have been registered under the transitional provisions by virtue of having "charitable purposes" in the sense required by the 1990 Act, ${ }^{68}$ but found subsequently by OSCR, under its recently launched "rolling review" of the register, not to meet the charity test. ${ }^{69}$ But the asset lock will also affect English and Welsh charities which - since the asset-locking provisions have no real equivalent in the English legislation ${ }^{70}$ - may unguardedly opt for registration unaware that opting out again may leave them with continuing compliance obligations in Scotland. ${ }^{71}$

\section{ASSERTION OF JURISDICTION}

The asset lock is one expression of the wider policy of the 2005 Act of asserting control over bodies which use the charity brand in Scotland. A body which registers with OSCR submits itself voluntarily to a full jurisdiction of supervision administered by OSCR with the support of the Court of Session. ${ }^{72}$ It should be emphasised that there is no requirement that the body should have a territorial connection with Scotland. In England and Wales, on the other hand, the definition of a "charity" for regulatory purposes implies a sufficient preexisting territorial connection to bring the relevant institution "within the control of the High Court in the exercise of the court's jurisdiction with respect to charities", the touchstone for such control being the court's ability to enforce its supervisory orders against the charity trustees. ${ }^{73}$

The Scottish approach opens up the possibility of a body established outside Scotland, and with no connection with the territory, submitting itself voluntarily to the jurisdiction of the OSCR. More importantly in practice, however, it also means that the 2005 Act asserts for OSCR and the Court of Session a full supervisory jurisdiction over bodies which are active in Scotland but whose main centre of operations, and whose principal assets, may be situated outside Scotland. ${ }^{74}$ There are obvious potential difficulties of enforcement, ${ }^{75}$ which are the main rationale for the High Court's (and the Charity Commission's) eschewing a parallel charities jurisdiction over institutions constituted with charitable purposes outside England and Wales but active within the territory. ${ }^{76}$ The enforcement problems have been solved for Scotland, at least in relation to bodies which have their main centre of operations in England and Wales, by the United Kingdom Parliament's having conferred on the Charity Commission an auxiliary jurisdiction of intervention over bodies entered in the Scottish register which are "managed or controlled wholly or mainly in or from England and

672005 Act, s. 30.

68 I.e. the English sense before its adjustment by the 2006 Act: see further below.

692005 Act, s. 3(6). See OSCR, Rolling Review: Pilot study report (Dundee: OSCR, 2007) (hereinafter "Rolling Review'), para. 1.10.

70 Cf. 1993 Act, s. 3(4)-(6); see P Luxton, The Law of Charities (Oxford: OUP, 2001) (hereinafter “Luxton”), paras 10.75-83.

71 Arguably the lock affects only assets of an English or Welsh charity either situated in Scotland, or representing sums raised from the public in Scotland: see Scotland Act, s. 29(2)(a) and 101(2). There is, however, no express limitation to this effect in the 2005 Act.

722005 Act, ss. 28-37.

731993 Act, s. 96(1), as explained in Gaudiya Mission v Brabmachary [1998] Ch 341. See also the 2006 Act, s. 1; also Luxton, ch. 11, especially paras 11.01-04.

74 S. 14 excepts from registration only bodies with no significant territorial connection with Scotland: see further below.

75 Even with the benefit of the Civil Jurisdiction and Judgments Act 1982, s. 18.

76 Gaudiya Mission v Brabmachary [1998] Ch 341, per Mummery LJ at 350-2. 
Wales". ${ }^{77}$ Issues of enforcement aside, however, the Scottish assertion of jurisdiction involves, for non-Scottish bodies already subject to a regime of compliance in their territory of establishment, submission to a second compliance regime, the burdens of which should be kept in mind by such bodies contemplating registration with OSCR.

The "policing provisions" under which OSCR and the Court of Session may take preventative action against a body which represents itself as a charity without being entitled to do so (whether by registering or under the s. 14 exception) serve to underline the difference between the Scottish and English approaches. OSCR's powers of intervention include power to direct a body which is falsely representing itself as a charity to stop doing so, power to restrict the transactions of the body, and power to "freeze" property held by a third party on the body's behalf. ${ }^{78}$ OSCR may also apply to the Court of Session for exercise of the court's similar but more extensive powers. ${ }^{79}$ The English system, too, seeks to police use of the charity brand - or at least of the "registered charity" brand - but more simply, by making it a criminal offence in England and Wales for a person to solicit money or property for an institution in association with a false representation that it is a "registered charity", by which is meant a charity registered with the Charity Commission. ${ }^{80}$ Such an arrangement permits, of course, the soliciting of funds in England and Wales on behalf of a body established in Scotland and registered with OSCR, without any requirement for secondary registration with the Charity Commission, provided no misleading claim is made that the body in question is registered in England and Wales. The key difference of approach between the two systems, however, is that the Scottish policing provisions are civil in character and assert a continuing jurisdiction of control over the offending body, whereas the English provisions merely punish the individual who perpetrates the misleading solicitation. ${ }^{81}$

\section{Scottish "charity test" versus English definition of "charity"}

In principle, therefore, but for the s. 14 exception, any body which wishes to call itself a charity in Scotland must register with OSCR and submit itself to the Scottish system of supervision. The gateway to registration is the charity test. The divergences between the Scottish test and the English definition of charity have, perhaps, produced the most troublesome of the unintended consequences of the 2005 Act to have become apparent so far.

As explained, the test was intended to be "very similar" to and "compatible" with the revised English definition of charity now enshrined in the 2006 Act. ${ }^{82}$ It can be said to meet the first of these objectives in that its overall structure resembles that of the English definition, but the Scottish test is not "compatible" with the English definition if by that is meant that it is sufficiently close to enable HMRC, without demur, to recognise as charitable for tax relief purposes all bodies which have passed the charity test and are registered with OSCR, or to enable OSCR, without demur, to treat as meeting the charity test all bodies which HMRC or the Charity Commission recognise as charities in terms of the English

771993 Act, s. 80(1) as amended by the Charities and Trustee Investment (Scotland) Act 2005 (Consequential Provisions and Modifications) Order 2006 (SI 2006 No. 242(S.2), Sch., para. 6. It appears that the Charity Commission could take action if a body established in England and Wales but registered in Scotland failed to adhere to the Scottish compliance regime.

782005 Act, s. 31(2) and (5)-(7).

792005 Act, s. 34(2) and (5)(b)-(g). There may be difficulties of enforcement here, too, which are not solved by the auxiliary jurisdiction of the Charity Commission over bodies entered in the Scottish register.

80 Charities Act 1992, s. 63

81 OSCR's and the court's policing powers include (civil) powers of direction and interdict against individuals making false representations: 2005 Act, ss. 28(1)(e), 31(5) and 34(3).

82 See n. 12 above. The term "revised" is preferred here to "reformed" because the effect of the 2006 Act is to adjust and rationalise the definition rather than reform it in any radical sense. 
definition. Compatibility in this sense is ruled out by numerous differences of detail between test and definition, some of which have only emerged as significant as OSCR has sought to apply the test in practice. ${ }^{83}$

\section{RESEMBLANCES}

The resemblances between the two are clear enough. Under the 2005 Act, the purposes of a "charity" in Scotland must "consist only of one or more of the charitable purposes" set out in the statute in a list drawn ultimately from the recital of "uses" contained in the preamble to the (English) Charitable Uses Act $1601 .{ }^{84}$ So also, under the 2006 Act, a charity in England and Wales must be "established for charitable purposes only", 85 charitable purposes being purposes which fall within the "descriptions of purposes" set out in a list which shares the same origins as the Scottish one. ${ }^{86}$ Again, under the 2005 Act, a charity must provide "public benefit in Scotland or elsewhere", 87 while under the 2006 Act a charity's charitable purpose or purposes must be "for the public benefit", 88 it being clear from the existing case law on public benefit (in principle preserved by the Act) that in certain circumstances a purpose directing the conferment of benefit outside the jurisdiction may satisfy the public benefit requirement. ${ }^{89}$ And under neither Act is it to be presumed that any "particular purpose" or "particular description of purpose" in the relevant statutory list is for the public benefit. 90

\section{“Charitable Purposes" Element}

The differences between test and definition appear, firstly, however, in their "charitable purposes" elements. There are minor variations in the substance of the two lists, ${ }^{91}$ but more importantly the 2005 Act lacks the "safety-net" provision included in the 2006 Act which keeps within the scope of "charity" purposes treated as charitable under the pre-revisal definition but not represented in the statutory list. ${ }^{92}$ The provisions for extending the lists to meet changing social circumstances in the future are also different. Under the 2005 Act, there may be added "any other purpose that may reasonably be regarded as analogous" to the purposes in the statutory list. ${ }^{93}$ Under the 2006 Act, analogies may be drawn, not only with the purposes in the statutory list, but also with purposes previously established as charitable but omitted from the list; and analogising is not the only technique available for extending the list - purposes that may be reasonably regarded as "within the spirit of" the listed or other previously established purposes may also be brought within the scope of

83 Some potential divergences, but by no means all, were anticipated by those who submitted evidence to the Communities Committee at Stage 1 of the passage of the Bill: Communities Committee, First Report (2005) (SP Paper 301, Session 2 (2005)) (hereinafter "Stage 1 Report"), vol. 2, pp. 13-30.

842005 Act, s. 7(2): see commentary on s. 7 in Cross and Ford.

852006 Act, s. 1(a).

862006 Act, s. 2(2). Both lists draw heavily on the Strategy Unit Report, paras 4.12-18 and box 4.2.

872005 Act, s. 7(1)(b).

882006 Act, s. 2(1).

89 Luxton, paras 5.56-66.

902005 Act, s. 8(1); 2006 Act, s. 3(2).

91 The most striking difference is that the 2006 Act includes in its list (at s. 3(2)(1)), but the 2005 Act omits, "the promotion of the efficiency of the armed forces of the Crown, or the efficiency of the police, fire and rescue services or ambulance services".

922006 Act, s. 2(4)(a).

932005 Act, s. 7(2)(p). 
charity. ${ }^{94}$ In principle, therefore, the range of charitable purposes under the English definition is wider, actually and potentially, than under the Scottish test.

\section{“PuBliC BENEFIT" ELEMENT - ACTIVITIES TEST}

There are significant divergences, also, between the public benefit elements of test and definition. The Scottish test is, overtly, an "activities test", 95 and requires OSCR to assess whether the activities undertaken by a body in pursuit of its charitable purposes actually provide public benefit - no presumption being made, as mentioned, that any particular purpose is for the public benefit. ${ }^{96}$ On the other hand, the English definition invites an assessment of whether an institution's charitable purpose, or each of its charitable purposes where more than one, is for the public benefit in terms of the existing (but ever evolving) ${ }^{97}$ case law on public benefit - though subject to adjustment of the pre-revisal case law to the effect that, as mentioned, no particular description of purpose is to be presumed to be for the public benefit. ${ }^{8}$ The focus of the Scottish test, in other words, is on what the body does overall, and of the English definition on the character of each of the institution's purposes according to the accumulated (but adjusted) case law on public benefit.

The distinction may not be fully perceptible in practice, because the Charity Commission, under its new obligation to "promote awareness and understanding of the operation of the public benefit requirement", 99 is set to compare the actual activities of charities with their declared purposes to ensure that they are in fact providing public benefit, as their charitable purposes require them to do. ${ }^{100}$ None the less, the difference of approach has the potential to lead to divergent decisions on charitable status in the two jurisdictions, since the Scottish test, by its nature, makes it difficult to predict how two bodies of the same general type will each fare at the hands of OSCR, ${ }^{101}$ whereas the Charity Commission remains bound by the specifics of previous decisions on public benefit. ${ }^{102}$

942006 Act, s. 2(2)(m) and (4)(b). The provisions reflect the pre-revisal case law: see J Warburton et al., Tudor on Charities 9th edn (London: Sweet \& Maxwell, 2003), paras 1-005 and 1-006.

95 For discussion of the concept in relation to the pre-revisal English definition, see C Mitchell, "Reviewing the Register", in C Mitchell and S R Moody, Foundations of Charity (Oxford: Hart Publishing, 2000), pp. 184-6 and 200-1.

962005 Act, s. 7(1)(b). Where an applicant for registration is not yet active OSCR must assess whether the activities it intends to pursue will provide public benefit. See, generally, OSCR, Draft Guidance, ss. 6-8.

97 See 2006 Act, s. 2(8), which takes account of a recognised feature of the pre-revisal definition: Scottish Burial Reform and Cremation Society v Glasgow Corporation [1968] AC 138, per Lord Wilberforce at 154E-G.

982006 Act, ss. 2(1)(b) and 3. Under the pre-revisal definition it was (rebuttably) presumed that a purpose falling under one of the first three of the "heads" of charity identified by Lord Macnaghten in Special Commissioners of Income Tax v Pemsel [1891] AC 531 at 560 (the relief of poverty, the advancement of education and the advancement of religion) was for the public benefit: see National Anti-Vivisection Society v IRC [1948] AC 31, per Lord Wright at 42.

991993 Act, s. 1(b)(3).

100 See Charity Commission, Charities and Public Benefit (London: Charity Commission, 2008), ss. G and H.

101 See OSCR's insistence in its pilot for the rolling review of the register that each charity will be reviewed on its “own merit": OSCR, Rolling Review, para. 1.6.

102 E.g. Re Resch's Will Trusts [1969] 1 AC 514 sets parameters on fee-charging and public benefit which the Charity Commission must respect in its guidance. 


\section{"Public benefit" element - CASE LAW}

A further distinction in the public benefit element has already given rise to differences in practice. The Scottish test replaces the established case law on public benefit ${ }^{103}$ - preserved, as mentioned, in the revised English definition subject to removal of the pre-revisal "presumption" - with statutory criteria to which "regard must be had" in determining whether a body provides public benefit. 104 The criteria are intended to "encapsulate" the pre-revisal case law, ${ }^{105}$ but are expressed so generally that the quirks and nuances of the accumulated case law can scarcely be represented. It is clear that OSCR may look to the public benefit case law for persuasive guidance on the meaning of the statutory formula but is not bound by it. ${ }^{106}$

Already it is apparent that OSCR does not intend to apply the "poverty exception" - a long-established feature of the accumulated case law ${ }^{107}$ - for the purposes of the charity test, ${ }^{108}$ thus excluding from registration in Scotland certain classes of bodies accepted as charitable in England and Wales and for United Kingdom tax relief purposes, such as friendly societies constituted for the relief of their members' own poverty. ${ }^{109}$

So, too, OSCR's treatment of "campaigning organisations" will be different from the Charity Commission's and HMRC's. In England and Wales, and for United Kingdom tax purposes, the issue of "campaigning" will continue to be governed by the line of cases which excludes from charitable status not only political parties as such but also organisations with "political" purposes in the extended sense that they are constituted to campaign directly for changes in the law, government policy or administrative decisions, whether in the United Kingdom or abroad. ${ }^{110}$ The 2005 Act, on the other hand, provides expressly that a body which is a political party, or one of whose purposes is to advance a political party, cannot be a charity. ${ }^{111}$ The implication is that the Scottish Parliament, by going thus far but no further, intended to exclude from registration with OSCR only bodies with "party political" purposes, leaving open the possibility that bodies campaigning, for instance, for changes in the law on the treatment of political prisoners in a foreign country might satisfy the charity test. ${ }^{112}$

\section{MINISTERIAL CONTROL}

One further element of the Scottish test marks it out as significantly divergent from the English definition. The test excludes from registration a body whose "constitution expressly permits the Scottish Ministers or a Minister of the Crown to direct or control its

103 The case law consists of the accumulated decisions of the English courts of chancery on charities and of the English, Scottish and Northern Irish courts on charitable relief under United Kingdom tax legislation.

1042005 Act, s. 8(2).

105 Remark of the Minister for Communities: Official Report, Plenary Session, 9 March 2005, col. 15097.

106 Remark of the Deputy Minister for Communities: Official Report, Communities Committee, 2 February 2005 , col. 1742. The same will apply to the Scottish Charity Appeals Panel and the Court of Session on appeals from decisions of OSCR on the charity test.

107 For a full review of the cases, see the speech of Lord Cross of Chelsea in Dingle v Turner [1972] AC 601.

108 Draft Guidance, s. 7.6(a).

109 Dingle v Turner [1972] AC 601, per Lord Cross at 617F-H.

110 McGovern v Attorney-General [1982] 1 Ch 32; reaffirmed in Southwood v Attorney-General [2000] WL 877698. See Charity Commission Board Paper No. (08) OBM 03 on Campaigning and Political Activities by Charities, for meeting on 31 January 2008, para. 3: the concern of the Board is to settle new guidance on campaigning which clarifies both the "freedoms and boundaries of the existing legal and regulatory framework". The commission's recent emphasis has been on freedoms, but the boundaries of the case law remain.

1112005 Act, s. 7(4)(c).

112 Draft Guidance, s. 5.3. 
activities". 113 This is a much stricter exclusionary condition than its equivalent under the English system and tax relief case law. ${ }^{114}$ It was directed principally at non-departmental public bodies, which the Scottish legislators considered should not have charitable status in Scotland even though entitled to charitable tax relief at United Kingdom level. ${ }^{115}$ It was always anticipated, however, that an exception would be made in the case of the five "national collections" institutions, ${ }^{116}$ and the Scottish Ministers were given power to disapply the exclusionary condition by order, ${ }^{117}$ which they duly exercised in favour of the collections. The Scottish Ministers have, however, recently announced that they are to use it again in favour of Scottish further education colleges, which have been unexpectedly found to fall foul of the condition. 118

\section{UNINTENDED CONSEQUENCES OF NON-COMPATIBILITY}

Clearly, therefore, the Scottish charity test as enacted has not proved "compatible" with the English definition of charity in the sense hoped for by the Scottish legislators that it would produce the same results in decisions on charitable status in all but the most exceptional of cases. ${ }^{119}$ The actual and potential divergence between the two has caused unexpected practical difficulties for two further types of body.

First, a body established in Scotland whose constitution defines its "charitable purposes" by express reference to the meaning of the term in United Kingdom taxation law - that is, according to the English definition - will fail the charity test because, since some purposes under the English definition may not be charitable under the Scottish test, the body's purposes will not "consist only of one or more of the charitable purposes" listed in the 2005 Act. ${ }^{120}$ This element of the test - equivalent to the English requirement that a charity should be established for charitable purposes only ${ }^{121}$ - is reinforced by a further provision that a body does not meet the charity test if its constitution allows it to distribute or otherwise apply its property for a non-charitable purpose at any time, even in the event of being wound up. ${ }^{122}$ It has become apparent that the constitutions of many bodies currently registered with OSCR under the transitional provisions contain clauses which offend these provisions, since it was common under the 1990 Act arrangements to define charitable purposes by reference to United Kingdom tax legislation. ${ }^{123}$ These bodies will be obliged to alter their constitutions - by narrowing the scope of the offending clauses to cover only purposes which would be charitable under the 2005 Act - if they are to pass the charity test when their turn for assessment comes up under the rolling review. ${ }^{124}$

1132005 Act, s. 7(4)(b).

114 Construction Industry Training Board v Attorney-General [1973] Ch 173.

115 Stage 1 Report, vol. 1, paras 110-25.

116 E.g. the National Galleries of Scotland.

1172005 Act, s. 7(5).

118 Announcement by the First Minister on 21 May 2008. See also OSCR, Rolling Review, para. 5.5.3.

119 See Joint Position Statement (2005) issued by HMRC and OSCR.

1202005 Act, s. 7(1) (emphasis added).

1212006 Act, s. 1(1)(a).

1222005 Act, s. 7(4)(a). This provision, too, was directed at non-departmental public bodies, and its impact on other bodies seems to have been unexpected. The Scottish Ministers have power to disapply the provision by order: 2005 Act, s. 7(5).

123 The practice assured both tax relief and Scottish charity status.

124 See, generally, OSCR, Briefing Note - Use of the terms "charitable" and "charitable purposes" in constitutions of charities in the Scottish Charity Register (Dundee: OSCR, 2008). 
Secondly, for similar reasons, the divergence excludes from registration in Scotland charities established in England and Wales whose charity trustees have discretionary powers - on a winding up or otherwise - to apply funds for "charitable purposes" generally. OSCR will read such powers appearing in the governing instrument of an English or Welsh charity as referring to charitable purposes in the meaning of the English definition, and as incompatible with the charity test, again because the range of English charitable purposes is in principle wider than the range permitted by the 2005 Act. Here, too, the solution lies for an English or Welsh charity eager to register with OSCR - in narrowing the scope of the offending powers to cover only purposes which would be charitable under the 2005 Act. ${ }^{125}$

For English and Welsh charities in this position, therefore, the charity test represents a formidable hurdle to registration in Scotland. English and Welsh charities constituted with no such discretionary powers must also, of course, conform their purposes to the restrictive requirements of the Scottish test. A further unintended consequence of the divergence between Scottish test and English definition may be to act as an additional disincentive additional to the asset lock and submission generally to the supervision of OSCR and the Court of Session - for English and Welsh charities to apply for recognition in Scotland.

\section{"Foreign" or "non-Scottish" charities' provisions}

As we have seen, it is a key principle of the 2005 Act that any body wishing to represent itself as a "charity" in Scotland must register with OSCR and submit to the Scottish regime of compliance. As also mentioned, however, there is a limited exception, under s. 14 of the Act, for "foreign" or "non-Scottish" charities. ${ }^{126}$ A body is a non-Scottish charity for the purposes of the section if it is: ${ }^{127}$

(i) established under the law of a country or territory other than Scotland,

(ii) entitled to refer to itself as a "charity" (by any means or in any language) in that country or territory, and

(iii) managed or controlled wholly or mainly outwith Scotland.

Before looking in greater detail at the exception, it may be helpful to consider the policy background to the Act's arrangements for non-Scottish charities in particular. If the primary intention of the Act is to protect the charity brand, what special considerations need to be taken into account in realising that aim in relation to charities constituted and based outside Scotland?

\section{POLICY BACKGROUND}

If it is a fundamental concern of the Act to protect benefactors in Scotland "against the corrupt use and abuse of the word "charity", 128 its aspiration must be that the public in Scotland should be able to contribute to non-Scottish charities, no less than to domestic ones, in the knowledge that the recipient bodies will be subject to a rigorous system of supervision. In the case of non-Scottish charities, however, there is the additional consideration that funds may be solicited in Scotland under the banner of charity with insufficient notice to benefactors that the funds raised may be applied outside Scotland.

125 See, generally, Charity Commission, Guidance for English and Welsh Charities that Have Been Asked to Amend their Governing Documents before They Can Register in Scotland (London: Charity Commission, 2007).

126 "Foreign" is used in the official Explanatory Notes to s. 14, but "non-Scottish" is preferred here as better suited to describe a class of bodies which in practice will mostly be established under the law of England and Wales: Explanatory Notes, para. 24.

1272005 Act, s. 14(a).

128 See n. 22 above. 
There is the further consideration that, where a non-Scottish "charity" is defined as such by reference to criteria different from those applied in Scotland under the charity test, Scottish benefactors may unwittingly contribute to causes which would not be treated as charitable in their own country.

The germ of the 2005 Act's response to these considerations lies in the McFadden Report. ${ }^{129}$ The report focused on the treatment of "national charities", that is, cross-border charities operating both in Scotland and in England and Wales, ${ }^{130}$ but concluded that "similar arrangements should apply to charities registered in other countries".131 Its "guiding principle" was "that any organisation that wants to get any benefits of being a Scottish Charity - including collecting money from the Scottish public by way of public charitable collections - should be registered with [the Scottish charity regulator]". ${ }^{132}$ What was envisaged, however, was dual registration, not dual regulation. The report proposed mutual recognition arrangements under which a body registered and regulated in England and Wales but active in Scotland would be registered in the Scottish register on an information-only basis, and vice versa. Members of the public in the "host" jurisdiction would be able to obtain basic details in their own country's register of any "guest" charity active in the jurisdiction and would be referred to the register of the country of establishment for further details. ${ }^{133}$

In the normal case, therefore, dual regulation would be avoided, on the basis that the compliance regime of the jurisdiction of establishment would provide a sufficient guarantee to the public of the host jurisdiction of the probity of the guest charity. None the less, it was suggested that the Scottish regulator should have discretion to require "full registration" (and by implication full compliance with the Scottish regime) for an English or Welsh charity active in Scotland, ${ }^{134}$ presumably to cover the special case of charities not fully regulated by the Charity Commission as exempt or excepted from registration. ${ }^{135}$ The "overriding consideration" for the McFadden Committee was that the public in Scotland should have, from one compliance regime or the other, "an assurance that charities in Scotland are being subject[ed] to appropriate scrutiny, coupled with public access to information". 136

The report's key points of information to the public and appropriate scrutiny were taken up in the Scottish Bill as introduced, and ultimately as enacted, but the McFadden mutual recognition proposals were all but dropped in favour of a hardened policy requirement that any organisation wishing to call itself a charity in Scotland and having "significant operations" in the jurisdiction should be registered with and regulated by OSCR. ${ }^{137}$ While it was accepted during the passage of the Bill that for charities registered with the Charity Commission this would involve some dual regulation it was anticipated that the two regulators would co-operate to minimise its impact. ${ }^{138}$ The mutual recognition concept survived in vestigial form in the exception in favour of English and Welsh and other nonScottish charities with no "significant operations" in Scotland permitting them to represent

129 McFadden Report, paras 3.22-8.

130 Ibid., para. 3.22 .

131 Ibid., para. 3.28 .

132 Ibid.

133 Ibid., paras 3.24-7.

134 Ibid., para. 3.23 .

135 The relevant provision is now 1993 Act, s. 3A.

136 McFadden Report, para. 3.24.

137 Policy Memorandum, paras 27, 57 and 58.

138 Ibid., para. 57. See Stage 1 Report, vol. 1, paras 21, 77 and 78. 
themselves as charities there, without registration with OSCR and concomitant regulation, if entitled to call themselves charities in their home jurisdiction. ${ }^{139}$

This is the policy to which the Act's provisions on registration and use of the charity brand, including the s. 14 exception, seek to give effect. OSCR has explained the provisions in its subsequent guidance to English and Welsh charities as:

... intended to provide a level playing field for all charities operating in Scotland, ensuring fairness and consistency [and] ... allowing the public to make informed decisions about donations to charity and providing assurance that charities are acting appropriately."140

The intention is, the guidance asserts, "to capture all charitable operations in Scotland within the regulatory regime", while yet recognising an appropriate distinction "between a significant operation in Scotland and an organisation which has only an occasional connection". 141

\section{SECTION 13}

While the overall policy may be clear enough, the detail of the provisions themselves is by no means straightforward. The express exception for non-Scottish charities is contained, as mentioned, in s. 14 of the 2005 Act, but that section must be read together with s. 13, which it qualifies. Section 13 must itself be read in the light of the "policing provisions" restraining unauthorised use of the charity brand in Scotland. ${ }^{142}$

It is s. 13 which articulates the key principle of the Act that only a body registered with OSCR may call itself a charity in Scotland. Subsection (1) provides that:

A body entered in the Register may refer to itself as a "charity", a "charitable body" a "registered charity" or a "charity registered in Scotland".

Subsection (3) goes on to provide that:

A body which refers to itself in any of the ways described in subsection (1)

is to be treated as representing itself as a body entered in the Register.

The exclusive right of bodies entered in the Scottish register to use the designations identified in subsection (1) is underpinned by the policing powers already mentioned: OSCR may investigate, and then initiate preventative action against "a body which is not entered in the Register which appears to OSCR to represent itself as a charity (or which would, but for section 14, so appear)". ${ }^{143}$ Subsections (2) and (4) of s. 13 contain subsidiary provisions restricting the use of the labels "Scottish charity" and "registered Scottish charity" to bodies either established under the law of Scotland, or managed or controlled wholly or mainly in or from Scotland, and these in turn are underpinned by corresponding policing provisions. ${ }^{144}$ The main question here, however, is whether, or in what circumstances, a non-Scottish charity - in particular one established in England and Wales - may properly make reference in Scotland to the fact that it is a charity in its home jurisdiction.

Read on its own, and if full weight is given to its use of quotation marks, s. 13 seems to leave open the possibility that a body not registered with OSCR may yet refer to its charitable status in its home jurisdiction by words or phrases other than those expressly

139 Policy Memorandum, para. 58 and the Scottish Bill, s. 14.

140 Guidance on Registration, s. 2.

141 Ibid., s. 2.

1422005 Act, ss. 28(1)(c), 31(2)(a), and 34(2).

1432005 Act, s. 28(1)(c).

1442005 Act, ss. 34(2)(b) and 34(4). 
proscribed. A body registered as a charity in England and Wales might, for instance, refer to itself as a body "registered with the Charity Commission". 145 On a literal reading of the section, such a charity would not be making use of any of the protected designations and ought to be outside the scope of the deeming provision. There would be nothing to prevent it, apparently, from operating freely in Scotland - from its own territorial foothold in the country if it chose - under the banner of a non-proscribed designation announcing, indirectly at least, its charitable status in England and Wales. ${ }^{146}$

\section{SECTION 14}

If that were a correct reading of s. 13, however, the s. 14 exception would be robbed of much of its force. Section 14 seeks to implement the policy that non-Scottish charities with no "significant operations" in Scotland are excepted from registration with OSCR, yet may still call themselves charities. ${ }^{147}$ It provides that a non-Scottish charity is entitled to refer to itself as a charity in Scotland without registering with OSCR, provided (a) that it does not either occupy any land or premises in Scotland or carry out activities in any office, shop or similar premises in Scotland, and (b) that when it refers to itself as a charity in Scotland it refers also to being established under the law of a country or territory other than Scotland. ${ }^{148}$

The point of the final condition - that an excepted body must make clear its nonScottish origin - is, of course, that members of the Scottish public are put on notice that they are dealing with a non-Scottish charity and may make or withhold donations after enquiry as they think fit. It will be seen, however, that the test of whether a body's operations are "significant" is territorial: does the body occupy any land or premises in Scotland, or does it otherwise carry on any activities in an office, shop or similar premises in Scotland? To benefit from the exception, and to be entitled to call itself a charity without registering with OSCR, a body must dispense with all but a minimal territorial foothold in Scotland. But if a non-Scottish charity can already, under s. 13, refer to itself circuitously as a charity by a designation other than one proscribed expressly by the section, and without restriction on its use of premises in Scotland, what is the point of the s. 14 exception?

Unsurprisingly, OSCR itself interprets the combined effect of ss. 13 and 14 robustly, to the effect of requiring, without nuance, that "all charities with significant operations in Scotland" must register. ${ }^{149}$ This is a robust reading in that it gives short shrift to circuitous references to charitable status elsewhere, treating them as a trigger to the requirement to register in Scotland no less than direct use of the charity brand, ${ }^{150}$ but there is also a concessionary element. Section 14 itself does not contain the word "significant", but on the face of it requires that a non-Scottish charity with any activities in the relevant types of premises must register with OSCR if it is to use the charity label in Scotland. ${ }^{151}$ The concession is clearly consistent with the declared policy behind the provision, and no doubt is a response to the 2005 Act's general exhortation to OSCR to "have regard to the principles under which regulatory activities should be proportionate . . and targeted only

\footnotetext{
145 This is a phrase which the Charity Commission regards as satisfying the requirement under the 1993 Act, s. 5(2) that a registered charity must make its status as such known on relevant documentation: see Luxton, para. 2.28 .

146 The Explanatory Notes, para. 22, seem to allow for such a reading.

147 Policy Memorandum, para. 27.

1482005 Act, s. 14(b) (emphasis added).

149 Guidance on Registration, s. 4.1.

150 Ibid., s. 4.2.a.

1512005 Act, s. 14(b)(ii).
} 
at cases in which action is needed". ${ }^{152}$ The effect is to broaden the scope of the exception, but it may be prudent for bodies intending to make use of s. 14 to bear in mind that the extension is, strictly speaking, concessionary. ${ }^{153}$

A final point to note is that s. 14 makes no distinction between activities directed towards fundraising and activities directed towards conferment of benefit. A non-Scottish charity with significant activities in Scotland is, accordingly, required to register with OSCR, even if it raises its funds entirely outside Scotland and engages only in service provision within the territory.

\section{ASSESSMENT OF PROVISIONS}

Are these provisions as to non-Scottish charities satisfactory? Possible criticisms of drafting aside, how do they fare against the McFadden criteria of information to the public and adequate scrutiny? Of non-Scottish charities which choose to register with OSCR - thereby, of course, becoming full-blown charities under the Scottish system as well as charities in their home jurisdiction - it can be said that the public in Scotland will have exactly the same level of information about them through the Scottish register, and that they will be subject to exactly the same degree of scrutiny by OSCR, as bodies established in Scotland which choose to register.

Of non-Scottish charities which take advantage of the s. 14 exception, it can be said that the public in Scotland will be positively alerted to the non-Scottish origin of any such body in the references it makes to itself as a charity, but that otherwise the level of information available will depend on the accessibility and quality of the registration system (if any) in the home jurisdiction of the body concerned. High quality information, including information about an individual institution's purposes, will, for instance, be readily available through the Charity Commission's electronic register about charities registered in England and Wales, but equivalent information about French bodies entitled to call themselves "charitable" or "caritatif" may be harder to come by. ${ }^{154}$ Likewise, the quality of scrutiny applied to a non-Scottish charity operating in Scotland under the s. 14 exception will depend on the supervisory arrangements in the body's home jurisdiction: a charity registered in England and Wales will be subject to a level of scrutiny very similar to that applied by OSCR, but in France no equivalent supervisory arrangements attach expressly to bodies entitled to call themselves charitable or caritatif. ${ }^{155}$ It can be argued, however, that since the activities in Scotland of bodies covered by the s. 14 exception will always (on OSCR's interpretation) be less than "significant", any deficiencies in information or scrutiny will be of marginal importance, though this may be to underestimate the capacity of an organisation based outside Scotland for mounting a fundraising campaign, electronically or by post, from its home jurisdiction.

A more serious criticism is that the default obligation to register - incumbent on all nonScottish charities active in Scotland other than those able to tailor their activities to the restrictive requirements of the s. 14 exception - may prove in the long run to be counterproductive. Registration in Scotland assures high levels of public information and scrutiny under the Scottish system itself, but in the case, in particular, of English and Welsh

1522005 Act, s. 1(9)(a).

153 A further example of inventive statutory interpretation by OSCR is its reading of the phrase "an office, shop or similar premises" to include church halls: Guidance on Registration, s. 4.2.f.

154 See Explanatory Notes, para. 24.

155 The equivalent regime is the utilité publique regime, but not all charitable or caritatif organisations are recognised as d'utilité publique: see, generally, D Lepeltier and Y Streiff, Associations, Fondations, Congrégations (Paris: GLN Joly, 1994). 
charities registered with the Charity Commission, duplicates public information and scrutiny already available through the English system. For the individual institutions concerned, the burdens of dual registration and dual regulation must act as a strong discouragement to activity in Scotland, whether by way of fundraising or - equally importantly from the point of view of the Scottish public - conferment of benefit. To assess whether there is a real risk of an "activity drain" from Scotland by non-Scottish charities, it may be helpful to look more closely at the options available to such bodies under the 2005 Act. Since the vast majority of non-Scottish charities likely to undertake activities in Scotland will be established in England and Wales, particular attention must be paid to the implications of the Scottish provisions for these cross-border charities. ${ }^{156}$

\section{To register or not to register?}

\section{REGISTER}

In principle, a non-Scottish charity with the relevant territorial connection with Scotland through occupation of land or premises or activities in an office, shop or similar premises - must register if it wishes to represent itself as a charity. What are the advantages of registration? As in the case of a body established in Scotland, they are access to the charity brand and, where relevant, charitable rates relief. It is questionable whether the other advantages available to bodies established in Scotland - access to reorganisation facilities and to the SCIO - are also available to non-Scottish charities, ${ }^{157}$ but in any event English and Welsh charities have equivalent advantages to those under their own system. The disadvantages of registration, on the other hand, are the constraints of the charity test and submission to the full supervisory jurisdiction for charities under the 2005 Act.

For English and Welsh charities, as we have seen, submission to the 2005 Act jurisdiction means dual regulation, by OSCR as well as the Charity Commission. Two regulators must be satisfied, each with slightly different requirements. Perhaps the most potentially troublesome of the areas of divergence between the two systems noted earlier are the treatment of charity trustee duties, the accounting and reporting requirements, and the operation of the Scottish asset lock on de-registration. ${ }^{158}$ OSCR and the Charity Commission have undertaken "to minimise the burden of dual regulation on cross border charities", 159 but differences in the primary provisions of the governing legislation must inevitably restrict the regulators' scope for harmonisation. For a charity registered in England and Wales, therefore, registration with OSCR will add to if not double the effort and expense of compliance.

\section{Alternative 1 - OPERATE WITHIN S. 14 EXCEPTION}

There are alternatives to registration. One would be for a non-Scottish charity to operate in Scotland without the benefit of a "significant" territorial foothold, under the s. 14 exception. An English charity, for instance, might carry out extensive fundraising operations in Scotland from across the border, by mail or email, or even by "public benevolent collection", 160

156 The same considerations will apply, however, mutatis mutandis, to bodies established in Northern Ireland or the Republic of Ireland once the systems of supervision currently proposed for those jurisdictions are in place.

157 Arguably, provision for the reorganisation of bodies established outside Scotland is beyond the competence of the Scottish Parliament, so that the relevant provisions (2005 Act, ss. 39-42) should be "read down" accordingly: Scotland Act 1998, s. 29(2)(a) and 101(2). Availability of the SCIO is limited to bodies with "a principal office in Scotland": 2005 Act, s. 49(2).

158 See pp. 204-9 above under "Scottish system of charities supervision outlined".

159 Memorandum of Understanding between OSCR and the Charity Commission (2007), para. 1.1.

160 I.e. in public places or visits to two or more private houses: 2005 Act, ss. 84-92. 
without making significant use of premises in Scotland. Such a charity might also bestow benefits from across the border, but a service-providing as opposed to grant-making charity might find itself severely restricted in what it could do by way of conferment of benefit without a significant territorial foothold. In any representation as to its charitable status the charity would have to refer to its non-Scottish origin, but it would be spared dual regulation.

\section{AlteRNATIVE 2 - HIVE OFF SCOTTISH OPERATIONS}

A second alternative for a non-Scottish charity might be to hive off the charity's Scottish operations to a separate body constituted in Scotland and registered with OSCR. Caution would be required, however. An English charity - again, the obvious example - might well lack power to transfer assets to a Scottish charity without an application to the Charity Commission for adjustment of its governing instrument; and its charity trustees would have to divest themselves of de facto control of the new Scottish entity in order to avoid being treated by OSCR as its true charity trustees. ${ }^{161}$ But in any event the creation of a second entity to be administered in Scotland would be likely to involve no less compliance administration overall than dual regulation of a single entity based in England.

\section{Alternative 3 - OPERATE AS A NON-REGISTERED "BeNEVOlent BODY"}

A third alternative, though fraught with complexity, might be to operate in Scotland with the benefit of a full territorial presence, but without the advantages of the charity brand and automatic charitable rates relief, as a non-registered (non-"charity") "benevolent body". 162 The principal difficulty here would be confronting OSCR's view that a body with significant activities in Scotland which calls itself a charity outside Scotland must register in the Scottish register even if it has no intention of using the charity label in Scotland. ${ }^{163}$ An English or Welsh charity would also wish to satisfy itself that failure to make known in Scotland its charitable status under English law would not be a breach of the publication requirements of the English legislation. ${ }^{164}$

\section{Alternative 4 - NON-ACTIVITY IN SCOTLAND}

Undoubtedly, the most straightforward alternative to registration in Scotland for a nonScottish charity would be non-registration and non-activity in the jurisdiction. For English and Welsh charities in particular, this would be a radical but complete solution to the problem of dual regulation. The asset-locking arrangements mean that it would be wiser for a non-Scottish charity hesitant about operating in Scotland not to register in the first instance than to opt subsequently to de-register.

\section{Conclusion}

This review of the options discloses, it is submitted, a real possibility that the 2005 Act's provisions for non-Scottish charities will in the long term discourage from engagement with Scotland organisations which under the pre-2005 Act arrangements would have seen subsidiary activity in Scotland as a natural extension of their principal activities in their home jurisdiction. The advantages of registration in Scotland are heavily offset by the disadvantages, and none of the available alternatives is fully satisfactory. The problem, for

1612005 Act, ss. 105 and 106. See OSCR, Guidance for Charity Trustees (Dundee: OSCR, 2006), para. 2.2.

1622005 Act, s. 79(1). Such a body might apply for discretionary rates relief.

163 OSCR, Guidance on Registration, s. 4.2.a. It is questionable whether the Scottish Parliament is competent to restrict what English and Welsh charities may call themselves in England and Wales: see n. 157 above.

1641993 Act, s. 5. These apply to charities with a gross annual income of more than $f 10,000$. Arguably the requirement has no application outside England and Wales: 1993 Act, s. 100. 
English and Welsh charities in particular, is that the dual regulation requirement does not so much "produce a level playing field" for all charities operating in Scotland as tilt the field to the prejudice of charities already subject to the burdens of compliance in an equivalent regime. Time will tell, but there must be a temptation for hard-pressed service-providing charities established south of the border to avoid the costs of double compliance by leaving the conferment of benefit in Scotland to the Scots. Ironically, such bodies might quite properly remain active in fundraising in Scotland, under the s. 14 exception, to the advantage of beneficiaries outside Scotland.

Such an outcome from the "foreign charities" provisions was not what the Scottish legislators intended. ${ }^{165}$ As enacted, however, the provisions are manifestly inconsistent with the 2005 Act's overall policy objective of establishing "a satisfactory regulatory regime that will encourage public confidence in charities whilst not over-burdening the charity sector with bureaucracy". ${ }^{166}$ For some non-Scottish charities already subject to regulation in their own jurisdiction, secondary regulation in Scotland may prove a bureaucratic burden too far. For those which do accept the burden of dual regulation, time, energy and resources will be expended on double compliance which might have been better spared for direct application to public benefit. ${ }^{167}$

\section{POSTSCRIPT - ALTERNATIVE TO DUAL REGULATION}

The worst of it is that the elaborate dual regulation arrangements are (it is suggested) unnecessary. Public confidence in charities might have been maintained but dual regulation avoided by adapting the English device for protecting the "registered charity" brand. As mentioned, it is a criminal offence in England and Wales to solicit contributions to an institution in association with a false claim that it is a "registered charity" - that is, a charity registered with the Charity Commission. ${ }^{168}$ The underlying policy is that members of the public in England and Wales are put on notice: they may give to an institution held out as a registered charity in the knowledge that it is supervised on an ongoing basis by the Charity Commission, and they may give to other institutions - such as non-charitable institutions constituted for benevolent or philanthropic purposes, or for that matter bodies established in Scotland and registered with OSCR - without that protection if they wish.

Corresponding provision might have been made in the 2005 Act to put members of the Scottish public on notice that a body for which funds were being solicited in Scotland was not registered with OSCR. But the provision might also have been refined to allow, expressly, solicitation of funds in Scotland on behalf of a charity registered in England and Wales - or in any jurisdiction judged to have an adequate system of charities registration and supervision, including, in due course, those in Northern Ireland and the Republic of Ireland ${ }^{169}$ - accompanied by a statement as to the charity's jurisdiction of origin and its status there as a registered charity. It would then be for individual members of the Scottish public to give or withhold their contributions as they thought fit in the light of the information available to them.

165 See Stage 1 Report, vol. 1, paras 21, 77 and 78.

166 Policy Memorandum, para. 24 (emphasis added).

167 The signs so far are ambivalent. The deadline for applications for registration from cross-border charities active in Scotland was the end of February 2007. From figures supplied by the courtesy of OSCR, it appears, as at 21 February 2008, that of just over 700 cross-border charities contacted by OSCR in advance of the deadline (as likely to be affected by the provisions) 525 had submitted applications. Of these 241 had been processed to registration, and a further 123 charities had undertaken to make changes to their constitutions to accommodate the charity test. The remaining 161 were still in correspondence with OSCR.

168 Charities Act 1992, s. 63.

169 Power to add appropriate jurisdictions by order might have been granted to the Scottish Ministers. 
Such arrangements might yet be introduced in Scotland by amendment of the 2005 Act, perhaps in legislation addressing some of the other unintended consequences of the statute noted above. Such arrangements would represent a return to the spirit of the McFadden mutual recognition proposals. In an electronic age, members of the public in Scotland would have as much access to information about non-Scottish charities in one of the corresponding jurisdictions - including information about the charities' purposes, different though they might be from those authorised by the Scottish charity test - as about bodies entered in OSCR's own internet-accessible register. ${ }^{170}$ Appropriate scrutiny would be provided through the home charities' supervision system in the relevant corresponding jurisdiction.

This, it is submitted, would be a simpler and no less effective means than dual regulation of "allowing the public [in Scotland] to make informed decisions about donations to charity and providing assurance that charities are acting appropriately". ${ }^{171}$ As a final postscript, a mutual recognition approach along these lines might be respectfully recommended to the legislators in Northern Ireland and the Republic of Ireland, who, perhaps unaware of the potentially unfortunate consequences, are on the verge of enacting, albeit with variations peculiar to each jurisdiction, dual regulation provisions reminiscent of the current arrangements for non-Scottish charities under the 2005 Act. ${ }^{172}$

170 The McFadden suggestion that information-only entries for "guest" charities should appear on the Scottish register (perhaps with an electronic link to the register of the charity's home jurisdiction) could be given effect on a voluntary basis, but compulsion would involve an assertion of jurisdiction over the charities in question with the attendant difficulties. "Small charities" and other charities excepted from registration in England and Wales could bring themselves within the mutual recognition scheme by registering voluntarily with the Charity Commission: 1993 Act, s. 3A.

171 Guidance on Registration, s. 2.

172 Charities Bill (NIA Bill 9/07), cl. 167; Charities Bill (No. 31 of 2007), ss. 38 and 42. 